\title{
Nurses' intention to leave their job and associated factors in Bahir Dar, Amhara Region, Ethiopia, 2017
}

\author{
Emiru Ayalew ${ }^{1 *}$ and Yinager Workineh ${ }^{2}$
}

\begin{abstract}
Background: Intention to leave is an employee's plan of tendency to leave the current working institute to find an alternative job in the near future. Even though nurses are the backbone of patient caring, there was no study done on intention to leave their job in North West Ethiopia. Therefore, the aim of this study was to assess nurses' intention to leave their job and associated factors in Bahir Dar, North West Ethiopia, 2017.

Methods: An institutional-based cross-sectional study was conducted from 1st March to 30th March 2017. After proportional sample size allocation, 210 participants were selected by simple random sampling method. Data were collected by using a self-administered structured questionnaire. Statistical Package for Social Science version 23.0 was used to enter, clean, code and analyze the collected data. The association between independent and dependent variables was assessed by using bivariable and multivariable logistic regression model. Factors that had statistically significant association with the dependent variable $(P<0.05)$ were identified as significant in the multivariable logistic regression analysis.
\end{abstract}

Result: From a total of 210 nurses, 191 of them were participating in this study making a response rate of 90.95\%. From all nurses, $64.4 \%$ of them were employed in the hospital. In this study, nurses' overall intention to leave their job was $64.9 \%$ (95\% Cl: [57.6, 71.2]). Nurses' intention to leave their job was determined by disagree in recognition $(\mathrm{AOR}=4.83 ; 95 \% \mathrm{Cl}:[1.73,13.50])$, and work itself (AOR $=31.30 ; 95 \% \mathrm{Cl}:[7.16,136.78])$.

Conclusion: Nurses' intention to leave their job in the current study was high. The contributing factors for this problem were disagree in recognition at work and work itself. Hence, we recommended that hospital and health center managers should maintain recognition at work and work itself to retain nurses.

Keywords: Intention to leave, Nurse, Factors, Ethiopia

\section{Background}

Intention is a mental process or activity that represent a binder to carrying out an action in the future [1]. Intention to leave is defined as one's behavioral attitude to leave the institution [2]. It is also defined as an employee's plan of tendency to leave the current

\footnotetext{
* Correspondence: emiruayalew2010@gmail.com

${ }^{1}$ Department of Adult Health Nursing, College of Medicine and Health Science, Bahir Dar University, Bahir Dar, Ethiopia

Full list of author information is available at the end of the article
}

working institute to find an alternative job in the near future [3-5]. Even if intention to leave does not essentially mean actual worker departure, it is a strong forecast of actual staff resigned or the level to that a member anticipates going the connection with the current community or employer [6-8].

Even though health care requires a more skilled work today as a result of advancement in medical technology for more sophisticated patient care [9], nurses' intention to leave their profession is a major problem or drawback

(c) The Author(s). 2020 Open Access This article is licensed under a Creative Commons Attribution 4.0 International License, which permits use, sharing, adaptation, distribution and reproduction in any medium or format, as long as you give appropriate credit to the original author(s) and the source, provide a link to the Creative Commons licence, and indicate if changes were made. The images or other third party material in this article are included in the article's Creative Commons licence, unless indicated otherwise in a credit line to the material. If material is not included in the article's Creative Commons licence and your intended use is not permitted by statutory regulation or exceeds the permitted use, you will need to obtain permission directly from the copyright holder. To view a copy of this licence, visit http://creativecommons.org/licenses/by/4.0/ The Creative Commons Public Domain Dedication waiver (http://creativecommons.org/publicdomain/zero/1.0/) applies to the data made available in this article, unless otherwise stated in a credit line to the data. 
worldwide particularly in Africa [10-12]. This problem brings losing of competent and qualified nurses [10-12]. As a result of such events, the shortage of nurses have created a health care crisis in developing countries by adversely affecting the quality of nursing care [13].

Several studies had shown a variable level of nurses' intention to leave their profession across the globe. A study conducted in the Midwestern region of the United States revealed that nurses had a high level of intention to leave their profession [14]. The similar studies carried out in Tanzania, Malawi and South Africa indicated that $18.8,26.5$ and $41.4 \%$ of health workers had the intention to leave their job to seek employment elsewhere respectively [15].

The main reason for nurses' intention to leave their job is to change the organization or profession and look forward new direction [16]. The evidence in Northern Italy stated that low job satisfaction, age $\geq 40$ years, and part-time schedule increased nurses' intention to leave their job [17]. Similarly, the study conducted in European countries pointed out that newly qualified and nearly retirement age nurses were more likely to leave their job [18]. Another previous study also indicated that the level of salary, availability of transport service, organizational policy, job dissatisfaction, working environment, work pressure and demographic factors was directly associated with nurses' intention to leave their profession [14, 19-21].

Nurses' intention to leave their profession has a significant impact on the performance, stability and productivity of the health facility. Thus, this issue should be received considerable attention worldwide specifically in developing countries since the evidence is scarce in such areas.

Assessing nurses' intention to leave their job is very necessary to plan nurse's retention mechanisms in the Ethiopian context. This study is also very important to add evidence for policy planners and program managers to improve such problems. Moreover, there were little or no studies done before on the issue of nurses' intention to leave their job in Ethiopia. Therefore, the purpose of this study was to assess the nurses' intention to leave their job and associated factors in Bahir Dar city, Amhara region, Northwest Ethiopia, 2017.

\section{Methods}

\section{Study design, setting and period}

The study was conducted in Bahir Dar public health institutions by using institutional-based cross-sectional study from 1st March to 30th March 2017. Bahir Dar is the capital city of the Amhara National, Regional State. It is located $565 \mathrm{~km}$ away from Addis Ababa (the capital city of Ethiopia) in the Northwest part of Ethiopia. It is the most beautiful city in Ethiopia that was awarded the prestigious UNESCO Cities Prize [22].

The public health centers in the city were Bahir Dar, Han, Shimbit, Shum Abo, Abay Mado, Zegie, Zenzelma, Tsiss Abay, Ginbot- 20 and Meshenti. Felege Hiwot and Addis Alem hospitals were the only public hospitals in this area. In addition to public health facilities, there were private hospitals, clinics, pharmacies and drug stores. According to the report of 2017, 8 MSc, 270 BSc and 163 diploma nurses were employed in Bahir Dar public health facilities.

\section{Sample size determination and sampling procedure}

The sample size was determined using a single population proportion formula. In this sample size calculation, $95 \%$ confidence intervals $(\mathrm{CI})$ with $\mathrm{Z} \alpha / 2$ value of 1.96 , $60.9 \%$ proportion (p) [23], 5\% margin of error (d) and $5 \%$ non-response rate were applied assumptions in this study.

$$
\begin{aligned}
& \mathrm{N}=\frac{\left(\mathrm{z}_{\alpha / 2}\right)^{2} \mathrm{p}(1-\mathrm{p})}{\mathrm{d}^{2}} \\
& \mathrm{~N}=\frac{(1.96)^{2} 0.0 .609(1-0.609)}{(0.05)^{2}}=365.9=366
\end{aligned}
$$

After the application of correction formula and 5\% non-response rate on the above value (366), the final sample size was 210 .

All public hospitals and health centers in Bahir Dar were included in the study. From each selected public health institutes, the number of nurses were gotten from monthly payrolls. Then, based on the number of nurses in each facility, the sample size was proportionally allocated by using "n = $(\mathrm{n} / \mathrm{N})$ "ni" formula (Fig. 1).

Finally, simple random sampling method was carried out to select the study participants from all categories of nurses in each health institution. We excluded nurses in annual, study, and maternity leave from the study participants.

\section{Measurement tool}

Data were collected by using pre-tested structured selfadministered questionnaire. This questionnaire was developed from previous different researches. The consistency of the questionnaire was ensured by translated the English version into the Amharic version and then back to English with the same expertise. Correction and modification of the questionnaire was performed after a pre-test on $5 \%$ of the total sample size. Three BSc nurses and one experienced public health officer were selected as data collectors and supervisor respectively. Two days training was given to both data collectors and 


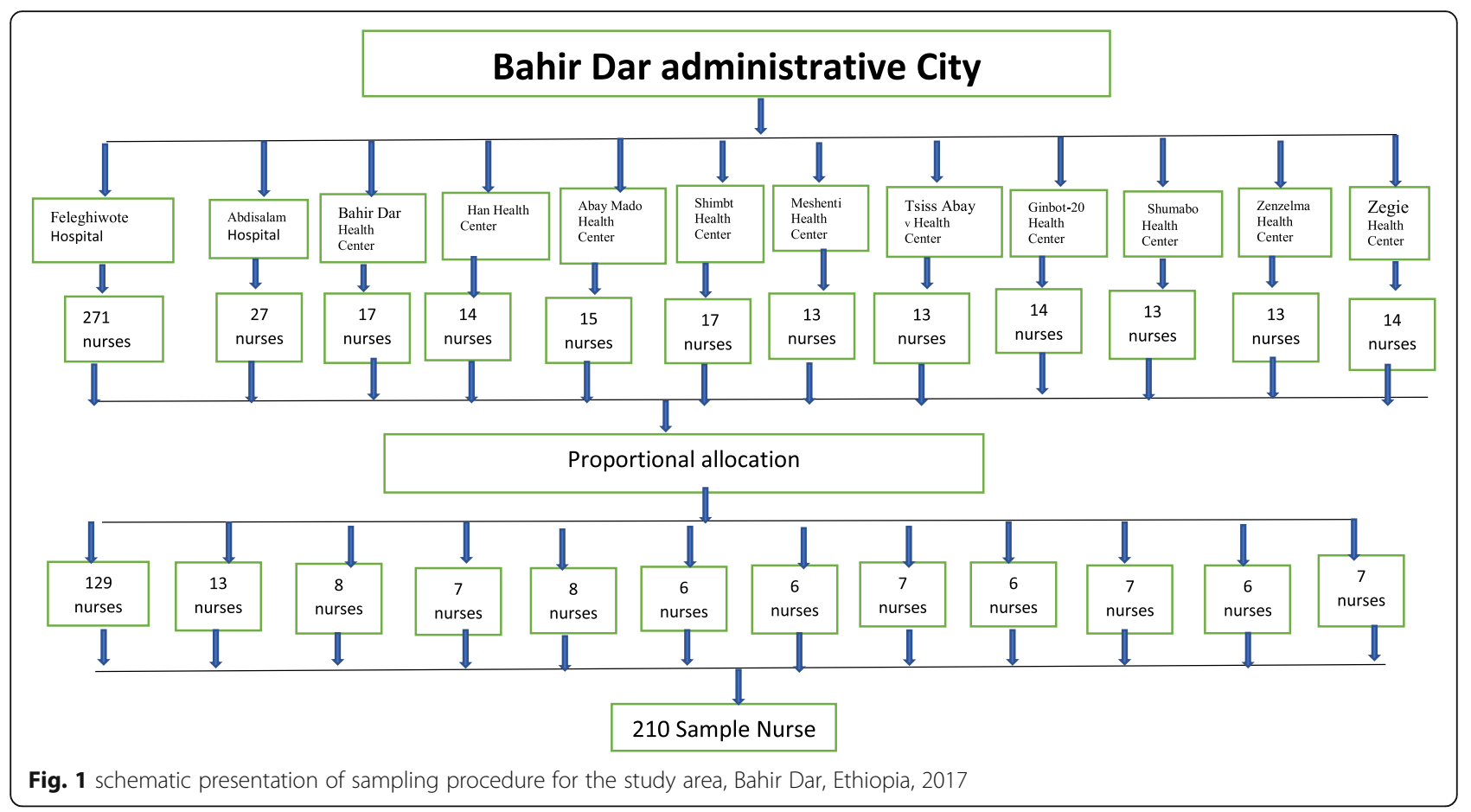

supervisor on the content of tools, and how to approach participants.

The socio-demographic characteristics and institutional factors were independent variables in the current study. The socio-demographic variables were age, work experience, level of education, and type of institution, whereas institutional factors were achievement, advancement, recognition at work, work itself, growth at work, organization policy, relationship with friends, relationship with supervisors, work security, payment and working conditions.

A 5-point Likert scale (strongly agree $=5$, agree $=4$, neither agree nor disagree $=3$, disagree $=2$, strongly disagree $=1$ ) was used to measure institutional factors [24, 25]. The response to these variables was categorized as agreed if the score $>=$ mean, and disagree if the score is below the mean.

Nurses' intention to leave their job, the dependent variable, was evaluated by Mark C Hand tool [26]. Seven items with a 5-point Likert were used in this instrument. The 5-point Likert scale ranged from 1 (strongly disagree) to 5 (strongly agree). Then the scores are categorized in low intent to leave (7 to 15), uncertain about intent to leave (16 to 25), and high intent to leave (26 to 35 ). Finally, the demarcation threshold formula: \{(total highest score-total lowest score) / two + total lowest score [27] was used to classify the outcome variables as intended to leave and unintended to leave.

\section{Data processing and analysis}

Statistical Package for Social Science (SPSS) version 23.0 was used to enter, clean, code and analyze collected data. Frequency distribution was performed. The association between independent and dependent variables was assessed by using bivariable and multivariable entered logistic regression model. In this model, the odds ratio with a $95 \%$ confidence interval was used to determine the strength of the association between dependent and independent variables. Those variables, with $P<0.2$ in the bivariable analysis model, were transferred to multivariable. Finally, factors that had statistically significant association with the dependent variable $(P<0.05)$ were identified as significant in the multivariable logistic regression analysis.

\section{Results}

Socio-demographic characteristics

One hundred ninety-one nurses participated in the study, making a response rate of $90.95 \%$. Among all nurses, 105 (55\%) were males. The mean age of nurses was 29.92 ( $\mathrm{SD} \pm 6.182$ ) years. Regarding to marital status, $110(57.6 \%)$ of them were married. From all category of nurses, $100(55.7 \%)$ were BSc nurses. From all participants, $62(34.3 \%)$ of them had 2-5 year of work experience. In the current study, the majority (64.4\%) of nurses were employed in the hospital (Table 1). 
Table 1 socio-demographic characteristics of study participant at Bahir Dar, Amhara Region, Ethiopia, 2017(N = 191)

\begin{tabular}{|c|c|c|c|}
\hline Variable & Category & Frequency & Percent \\
\hline \multirow[t]{2}{*}{ Sex } & Male & 105 & 55 \\
\hline & Female & 84 & 45 \\
\hline \multirow[t]{4}{*}{ Current age in year } & $20-30$ & 126 & 66.3 \\
\hline & $31-40$ & 53 & 27.1 \\
\hline & $41-50$ & 11 & 6.1 \\
\hline & $\geq 51$ & 1 & 0.6 \\
\hline \multirow[t]{4}{*}{ Marital status } & single & 54 & 28.3 \\
\hline & Married & 110 & 57.6 \\
\hline & Divorce & 14 & 7.3 \\
\hline & Widowed & 13 & 6.8 \\
\hline \multirow[t]{4}{*}{ Religion } & Orthodox Tewahedo & 113 & 59.2 \\
\hline & Protestant & 31 & 16.2 \\
\hline & Muslim & 24 & 12.6 \\
\hline & Other & 23 & 12.0 \\
\hline \multirow[t]{3}{*}{ Ethnicity } & Amhara & 166 & 86.9 \\
\hline & Oromo & 11 & 5.8 \\
\hline & ${ }^{\mathrm{a}}$ Other & 14 & 7.3 \\
\hline \multirow[t]{3}{*}{ Educational status } & Diploma nurse & 79 & 41.4 \\
\hline & BSc nurse & 108 & 56.5 \\
\hline & MSC & 4 & 2.1 \\
\hline \multirow[t]{4}{*}{ Work experience } & $<2$ year & 73 & 38.2 \\
\hline & 2-5 year & 34 & 17.8 \\
\hline & 5-10 year & 38 & 19.9 \\
\hline & $>10$ year & 46 & 24.1 \\
\hline \multirow[t]{2}{*}{ Institution } & Hospital & 123 & 64.4 \\
\hline & Health center & 68 & 35.6 \\
\hline
\end{tabular}

${ }^{a}$ Tigrie, GUmuze, Kembata, Sidama

Level of nurses' intention to leave their job

From all participants, 64.9\% (95\% CI: [57.6, 71.2]) of them had intention to leave their job. Among the study participants who had the intention to leave, $53.4 \%$ of them had a high level of intention to leave their job (Table 2).

Table 2 Nurses intention to leave their job in Bahir Dar, Amhara Region, Ethiopia, 2017( $N=191)$

\begin{tabular}{llll}
\hline Variables & Responses & Frequency & Percent \\
\hline $\begin{array}{l}\text { Nurse intention to their } \\
\text { job }\end{array}$ & Intention to leave & 123 & 64.6 \\
& $\begin{array}{l}\text { Not intentional to } \\
\text { leave }\end{array}$ & 68 & 35.4 \\
Levels of intention to & Highly intended & 66 & 53.4 \\
leave & Uncertain & 47 & 38.7 \\
& Low intended & 10 & 7.9 \\
\hline
\end{tabular}

\section{Factors associated with nurses' intention to leave their} job

After application of multivariable logistic regression model, only work itself and recognition at work was the main determinants of nurses' intention to leave their job. For instance, those study participants who disagreed with work itself in their organization were 31.30 times (AOR: 31.30; 95\%CI: [7.16, 136.78]) more likely to leave their job as compared their counterparts. Similarly, those study participants who disagreed in the recognition given to their work had 4.83 odds (AOR: 4.83; 95\% CI: $[1.73,13.50])$ of intention to leave their job than their counterparts (Table 3 ).

\section{Discussion}

The current study was aimed to assess nurses' intention to leave their job and associated factors by using a crosssectional study in Bahir Dar North West Ethiopia. Focused on such objective, $64.9 \%$ of nurses hand the intention to leave their job in the current area. This finding is consistent to the studies conducted in Jeddah City (61.5\%) [28], Jordan (60.9\%) [12], Jimma zone (63.7\%) [29] and East Gojjam zone (59.4\%) [23].

On the other hand, the present finding is higher than studies done in Gondar (52.5\%) [30] and Sidama (50\%) [10]. The reason for such difference might be variation in health facility and categories of health professions in the current and previous study sites. Our study participants are nurses from both hospitals and health centers, whereas the previous study participants were all health workers from hospitals. Similarly, the studies conducted in Tanzania (18.8\%), Malawi (26.5), South Africa (41.4\%), Saudi Arabia (40\%), Macao (39\%) and Iran (21\%) $[15,17,31-33]$ revealed that the proportion of nurses' intention to leave their job was lower than the current study. The presence of ongoing interventions, attractive salary (incentives), and better infrastructures in the above countries [34-37] brings lower level of nurses' intention to leave their job than in the present site.

This finding indicated that the demographic characterstics such as sex and mean age of the participants were different from the studies carried out in the other corner of the globe. The mean age of the participants this study was 29.92 years that is younger than studies done in Rwanda, Turkey, and Iran [38-40].

In the current study, $53.6 \%$ of nurses were male which are similar to the study done in Wollega Ethiopia [41]. On the other hand, the current finding is higher than the study conducted in the United States (7\%) [42] and Iran 12.7\% [39]. The main reason for Ethiopia male to join the nursing profession is to easily fix their job as compared with other professions. 
Table 3 Factors associated with intention to leave their job in Bahir Dar, Amhara Region, Ethiopia, 2017(N = 191)

\begin{tabular}{|c|c|c|c|c|c|}
\hline \multirow[t]{2}{*}{ Variables } & \multirow[t]{2}{*}{ Categories } & \multicolumn{2}{|c|}{ Level of Intention } & \multicolumn{2}{|l|}{ OR $(95 \% \mathrm{Cl})$} \\
\hline & & $\begin{array}{l}\text { Intended to } \\
\text { leave N (\%) }\end{array}$ & $\begin{array}{l}\text { Not Intended } \\
\text { to leave N (\%) }\end{array}$ & COR $(95 \% \mathrm{Cl})$ & AOR $(95 \% \mathrm{Cl})$ \\
\hline \multirow[t]{2}{*}{ Sex } & Male & $71(66.7)$ & $34(32.4)$ & 1.00 & \\
\hline & Female & $53(61,6)$ & $33(38.4)$ & $1.3(0.72,2.36)$ & $0.99(0.43,2.29)$ \\
\hline \multirow[t]{4}{*}{ Age } & $20-30$ & $45(35.7)$ & $81(64.3)$ & & \\
\hline & $31-40$ & $18(34)$ & $35(66)$ & & \\
\hline & $41-50$ & $7(63.6)$ & $4(36.4)$ & & \\
\hline & $>=51$ & $0(00)$ & $1(100)$ & 1.00 & \\
\hline \multirow[t]{4}{*}{ Work experience } & $<2$ year & $52(71.2)$ & $21(28.8)$ & $1.45(0.66,3.18)$ & \\
\hline & 2-5 year & 19(55.9) & $15(44.1)$ & $0.74(0.30,1.83)$ & \\
\hline & 5-10 year & $24(63.2)$ & 14(36.8) & $1.10(0.41,2.45)$ & \\
\hline & $>10$ year & $29(63)$ & $17(37)$ & 1.00 & \\
\hline \multirow[t]{3}{*}{ Level of education } & Diploma & $49(62)$ & $30(38)$ & $0.54(0.05,5.48)$ & \\
\hline & $\mathrm{BSC}$ & $72(66.7)$ & $36(33.3)$ & $0.67(0.07,6.64)$ & \\
\hline & MSC & $3(75)$ & $1(25)$ & 1.00 & \\
\hline \multirow[t]{2}{*}{ Institution } & Hospital & $76(61.8)$ & $47(38.2)$ & 1.00 & \\
\hline & Health center & 48(70.6) & $20(29.4)$ & $1.48(0.79,2.80)$ & $1.28(0.48,3.40)$ \\
\hline \multirow[t]{2}{*}{ Achievement } & Agree & $70(56)$ & $55(44)$ & 1.00 & \\
\hline & Disagree & $54(81.8)$ & $12(18.2)$ & $3.54(1.72,7.25) * *$ & $1.40(0.51,3.86)$ \\
\hline \multirow[t]{2}{*}{ Advancement } & Agree & $41(52.6)$ & $37(47.4)$ & 1.00 & \\
\hline & Disagree & $83(73.5)$ & $30(26.5)$ & $2.59(1.36,4.59) * *$ & $1.52(0.68,3.41)$ \\
\hline \multirow[t]{2}{*}{ Recognition at work } & Agree & $60(52.6)$ & $54(47.4)$ & 1.00 & \\
\hline & Disagree & $64(83.1)$ & $13(16.9)$ & $4.43(2.2,8.93) * *$ & $4.83(1.73,13.50) * *$ \\
\hline \multirow[t]{2}{*}{ Work it self } & Agree & $38(42.2)$ & $52(57.8)$ & 1.00 & \\
\hline & Disagree & $86(85.1)$ & $15(14.9)$ & $7.85(3.94,15.64) * *$ & $31.30(7.16,136.78) *$ \\
\hline \multirow[t]{2}{*}{ Growth at work } & Agree & $74(56.1)$ & $58(43.9)$ & 1.00 & \\
\hline & Disagree & $50(84.7)$ & $9(15.3)$ & $4.35(2.20,8.93) * *$ & $2.49(0.88,7.00)$ \\
\hline \multirow[t]{2}{*}{ Organization policy } & Good & $34(48.6)$ & $36(51.4)$ & 1.00 & \\
\hline & Poor & $90(74.4)$ & $31(25.6)$ & $3.07(1.65,5.72) * *$ & $0.21(0.04,1.11)$ \\
\hline \multirow[t]{2}{*}{ Relationship with friends } & Agree & $56(56)$ & $44(44)$ & 1.00 & \\
\hline & Disagree & $68(74.7)$ & $23(25.3)$ & $2.32(1.26,4.30) * *$ & $2.69(.087,8.39)$ \\
\hline \multirow[t]{2}{*}{ Relationship with supervisors } & Agree & $42(55.3)$ & $34(44.7)$ & 1.00 & \\
\hline & Disagree & $82(71.3)$ & $33(28.7)$ & $2.01(1.10,3.69) * *$ & $0.64(0.25,1.68)$ \\
\hline \multirow[t]{2}{*}{ Work security } & Agree & $21(41.2)$ & $30(58.8)$ & 1.00 & \\
\hline & Disagree & 103(73.6) & $37(26.4)$ & $3.98(2.03,7.79) * *$ & $2.70(0.87,8.38)$ \\
\hline \multirow[t]{2}{*}{ Payment } & Agree & $53(64.6)$ & 29(35.4) & 1.00 & \\
\hline & Disagree & $71(65.1)$ & $38(34.9)$ & $1.02(0.56,1.86)$ & $0.07(0.01,1.70)$ \\
\hline \multirow[t]{2}{*}{ Working condition } & Agree & $43(60.6)$ & 28(39.4) & 1.00 & \\
\hline & Disagree & $81(67.5)$ & $39(32.5)$ & $1.35(0.74,2.50)$ & $7.61(0.72,80.82)$ \\
\hline
\end{tabular}

${ }^{*} \mathrm{P}<0.05,{ }^{* *} \mathrm{P}<0.005$

In the current study, the main determinants of nurses' intention to leave their job was recognition at work and work itself. Nurses who disagreed on the recognition given in their workplace were more likely to leave their job than their counterparts. This finding is consistent with the studies done in India, Malaysia, China, Saudi Arabia, Sweden, Tigray, Bangladesh, and Pakistan [31, 43-48]. The reason for a high level of nurses' intention to leave their job in this regard was due to lack of acknowledging the employees' efforts and their 
accomplishments through praise, respect, and thanks [49-54]. The other evidence also pointed out that nurses intended to leave their job unless they received support from their managers [55]. Hence, constructive recognition should be given to promote nurse's retention and provide better care to patients.

Similarly, the current finding stated that participants who disagreed on the work itself in their organization had more fold of intention to leave their job as compared with their counter parts. This finding was in line with studies conducted in New Delhi (India), Malaysia, and China [43, $56,57]$. The main reason for a high level of intention to leave among participants who disagreed on the work itself in their institution is as a result of the negative impact of work satisfaction on nurses' motivation and organizational profitability [58]. The other evidence also stated that the work itself harms worker retention [31, 59].

\section{Conclusion}

Nurses' intention to leave their job in the current study was high. The contributing factors for this problem were disagree in recognition at work and work itself. Hence, we recommended that hospital and health center managers should maintain recognition at work and work itself to retain nurses.

\section{Supplementary information}

Supplementary information accompanies this paper at https://doi.org/10. 1186/s12912-020-00439-5.

Additional file 1. Questionnaire.

\section{Abbreviations}

AOR: Adjusted odds ratio; Cl: Confidence interval; COR: Crowd Odd Ratio; FHRH: Felege Hiwot referral hospital; HC: Health Center; OR: Odds ratio; P: Prevalence; SPSS: Statistical Package for Social Science

\section{Acknowledgements}

The authors are grateful to the nurses and data collectors who participated in the study. Besides, the authors would like to thank the head of each selected institutions for their cooperation in undertaking research endeavors.

\section{Authors' contributions}

EA is the primary investigator responsible for the overall research project. EA and YW have involved in the conceptualization and design of the study, data analysis, interpretation of findings, and writing and revision of the manuscript. All authors were involved in the writing of the manuscript and have approved the final version of the manuscript

\section{Funding}

This research received no specific grant from any funding agency in the public, commercial, or not-for-profit sectors.

\section{Availability of data and materials}

Data of this study will be obtained by contacting the corresponding author via this email: emiruayaew2010@gmail.com or Tel no. +251912121688.

\section{Ethics approval and consent to participate}

The study was approved by the Scientific Ethical Review Committee of Bahir Dar University with Protocol number-0013/17-05. Permission letters were obtained from Amhara Regional health office and respective institutions.
Written consent was obtained from nurses after a detailed explanation of the purpose of the study. Any involvement of the nurses was after their complete written consent. Nurses were told as they would have the right to withdraw from the study at any time during the study.

\section{Consent for publication}

Not applicable.

\section{Competing interests}

The authors declare that they have no competing interests.

\section{Author details}

${ }^{1}$ Department of Adult Health Nursing, College of Medicine and Health Science, Bahir Dar University, Bahir Dar, Ethiopia. ${ }^{2}$ Department of Child Health Nursing, College of Medicine and Health Science, Bahir Dar University, Bahir Dar, Ethiopia.

Received: 12 February 2019 Accepted: 29 May 2020

Published online: 08 June 2020

\section{References}

1. Flinkman M, Salanterä S. Early career experiences and perceptions-a qualitative exploration of the turnover of young registered nurses and intention to leave the nursing profession in F inland. J Nurs Manag. 2015; 23(8):1050-7.

2. Aydogdu S, Asikgil B. An empirical study of the relationship among job satisfaction, organizational commitment and turnover intention. Int Rev Manag Mark. 2011;1(3):43-53.

3. Vandenberg RJ, Nelson JB. Disaggregating the motives underlying turnover intentions: when do intentions predict turnover behavior? Hum Relat. 1999; 52(10):1313-36

4. Cohen G, Blake RS, Goodman D. Does turnover intention matter? Evaluating the usefulness of turnover intention rate as a predictor of actual turnover rate. Rev Public Pers Adm. 2016;36(3):240-63.

5. Alam MM, Mohammad JF. Level of job satisfaction and intent to leave among Malaysian nurses. Bus Intell J. 2010:3(1):123-37.

6. Kim SW, Price JL, Mueller CW, Watson TW. The determinants of career intent among physicians at a US Air Force hospital. Hum Relat. 1996;49(7):947-76.

7. Rahim MA, Psenicka C. A structural equations model of stress, locus of control, social support, psychiatric symptoms, and propensity to leave a job. J Soc Psychol. 1996;136(1):69-84.

8. Griffeth RW, Hom PW, Gaertner S. A meta-analysis of antecedents and correlates of employee turnover: update, moderator tests, and research implications for the next millennium. J Manag. 2000;26(3):463-88.

9. Almalki MJ FG, Clark M. The relationship between quality of work life and turnover intention of primary health care nurses in Saudi Arabia. BMC Health Serv Res. 2012;12(1):314-41.

10. Asegid A, Belachew T, Yimam E: Factors influencing job satisfaction and anticipated turnover among nurses in Sidama zone public health facilities,South Ethiopia. Nurs Res Pract. 2014;2014:1-27.

11. Rhoades $L$, Eisenberger R. Perceived organizational support: a review of the literature. J Appl Psychol. 2002;87(4):698

12. Al Momani M. Factors influencing public hospital nurses' intentions to leave their current employment in Jordan. Int J Community Med Public Health. 2017;4(6):1847-53

13. Kaddourah B, Abu-Shaheen AK, Al-Tannir M. Quality of nursing work life and turnover intention among nurses of tertiary care hospitals in Riyadh: a cross-sectional survey. BMC Nurs. 2018:17(1):43.

14. Tschannen D, Kalisch BJ, Lee KH. Missed nursing care: the impact on intention to leave and turnover. CJNR (Canadian Journal of Nursing Research). 2010;42(4):22-39.

15. Blaauw D, Ditlopo P, Maseko F, Chirwa M, Mwisongo A, Bidwell P, Thomas $\mathrm{S}$, Normand C. Comparing the job satisfaction and intention to leave of different categories of health workers in Tanzania, Malawi, and South Africa. Glob Health Action. 2013:6(1):19287.

16. Simon M, Müller BH, Hasselhorn HM. Leaving the organization or the profession-a multilevel analysis of nurses' intentions. J Adv Nurs. 2010; 66(3):616-26

17. Cortese C. Predictors of critical care nurses' intention to leave the unit, the hospital, and the nursing profession. Open J Nurs. 2012;2(3A):311-26. 
18. Heinen MM, van Achterberg T, Schwendimann R, Zander B, Matthews A, Kózka M, Ensio A, Sjetne IS, Casbas TM, Ball J. Nurses' intention to leave their profession: a cross sectional observational study in 10 European countries. Int J Nurs Stud. 2013;50(2):174-84.

19. Oliveira DR, Griep RH, Portela LF, Rotenberg L. Intention to leave profession, psychosocial environment and self-rated health among registered nurses from large hospitals in Brazil: a cross-sectional study. BMC Health Serv Res. 2017;17(1):21.

20. Coomber B, Barriball KL. Impact of job satisfaction components on intent to leave and turnover for hospital-based nurses: a review of the research literature. Int J Nurs Stud. 2007:44(2):297-314.

21. Aiken LH, Sloane DM, Bruyneel L, Van den Heede K, Griffiths P, Busse R, Diomidous M, Kinnunen J, Kózka M, Lesaffre E, McHugh MD. Nurse staffing and education and hospital mortality in nine European countries: a retrospective observational study. The lancet. 2014;383(9931):1824-30.

22. Matsuura K. Address by Mr Koïchiro Matsuura Director-General of the United Nations Educational, Scientific and Cultural Organization. Moscow: 2004: (UNESCO) on the occasion of the World Congress of News Agencies; 2004

23. Getie GA, Betre ET, Hareri HA. Assessment of factors affecting turnover intention among nurses working at governmental health care institutions in east Gojjam, Amhara region, Ethiopia, 2013. Am J Nurs Sci. 2015;4(3):107-12.

24. Weiss DJ, Dawis RV, England GW, Lofquist LH. Manual for the Minnesota Satisfaction Questionnaire: Minnesota studies in vocational rehabilitation. Minneapolis: Industrial Relations Center, University of Minnesota;1967.

25. Baylor KM. The influence of intrinsic and extrinsic job satisfaction factors and affective commitment on the intention to quit for occupations characterized by high voluntary attrition; 2010.

26. Hand MC. Job satisfaction and intent to leave of nursing assistants in a hospital setting; 2015.

27. Argago TG, Hajito KW, Kitila SB. Clients satisfaction with family planning services and associated factors among family planning users in Hossana town public health facilities, South Ethiopia: facility-based cross-sectional study. Int J Nurs Midwifery. 2015;7(5):74-83.

28. Alharthi R, Damanhouri AMS. Factors Influencing Saudi Nurses Turnover "Empirical Study in Ministry of Health Hospitals- Jeddah City". IJERM. 2018;05(02): $1-10$.

29. Kalifa T, Ololo S, Tafese F. Intention to leave and associated factors among health professionals in Jimma zone public health centers, Southwest Ethiopia. Open J Prev Med. 2016;6(01):31.

30. Abera E, Yitayal M, Gebreslassie M. Turnover intention and associated factors among health professionals in University of Gondar Referral Hospital, Northwest Ethiopia. Int J Econ Manag Sci. 2014;3(4):1-4.

31. Alshmemri M. Job satisfaction of Saudi nurses working in Saudi Arabian public hospitals; 2014.

32. Sojane JS, Klopper HC, Coetzee SK. Leadership, job satisfaction and intention to leave among registered nurses in the north west and Free State provinces of South Africa. Curationis. 2016;39(1):1-10.

33. Chan MF, Luk AL, Leong SM, Yeung SM, Van IK. Factors influencing Macao nurses' intention to leave current employment. J Clin Nurs. 2009; 18(6):893-901.

34. Abduljawad A, Al-Assaf AF. Incentives for Better Performance in Health Care. SQU Med J. 2011:11(2):201.

35. Hongoro C, Normand C. Health workers: building and motivating the workforce. Disease control priorities in developing countries. 2006;2:22.

36. Osibanjo AO, Adeniji AA, Falola HO, Heirsmac PT. Compensation packages: a strategic tool for employees' performance and retention. Leonardo J Sci. 2014:25:65-84

37. Feather RA, Ebright $P$, Bakas T. Nurse Manager Behaviors That RN s Perceive to Affect Their Job Satisfaction. InNursing Forum. 2015;50(2):125-36.

38. Ufashingabire CM, Nsereko E, Njunwa KJ, Brysiewicz P. Knowledge and attitudes of nurses regarding pain in the intensive care unit patients in Rwanda. Rwanda J. 2016;3(1):21-6.

39. Sadat Z, Aboutalebi MS, Alavi NM. Quality of work life and its related factors: A survey of nurses. Trauma Monthly. 2017;22(3):777-80.

40. Obioha JA, Ikechebelu Jl, Eleje GU, Joe-Ikechebelu NN. Knowledge and attitude of nurses towards in-vitro fertilization: A prospective cohort study. Obstet Gynaecol Cases-Reviews. 2014;1(1):2-8.

41. Ebi WE, Hirko GF, Mijena DA. Nurses' knowledge to pressure ulcer prevention in public hospitals in Wollega: a cross-sectional study design. BMC Nurs. 2019;18(1):20.
42. Barrett-Landau S, Henle S. Men in nursing: their influence in a female dominated career. J Leadersh Instr. 2014;13(2):10-3.

43. Tan TH, Waheed A. Herzberg's motivation-hygiene theory and job satisfaction in the Malaysian retail sector: the mediating effect of love of money; 2011

44. Gotvassli K- $\AA$, Haugset AS. Job satisfaction and job performance-impacts on human capital; 2010

45. Ayamolowo SJ. Job satisfaction and work environment of primary health care nurses in Ekiti state, Nigeria: an exploratory study. Int J Caring Sci. 2013; 6(3):531.

46. Lagerlund M, Sharp L, Lindqvist R, Runesdotter S, Tishelman C. Intention to leave the workplace among nurses working with cancer patients in acute care hospitals in Sweden. Eur J Oncol Nurs. 2015;19(6):629-37.

47. Rudman A, Gustavsson P, Hultell D. A prospective study of nurses' intentions to leave the profession during their first five years of practice in Sweden. Int J Nurs Stud. 2014;51(4):612-24.

48. Berhe $\mathrm{H}$. Job satisfaction of nurses and associated factors in public hospitals in Tigray region, Northern Ethiopia. Greener J Med Sci. 2014;4(1):022-37.

49. Blegen MA, Goode CJ, Johnson M, Maas ML, McCloskey JC, Moorhead SA. Recognizing staff nurse job performance and achievements. Res Nurs Health. 1992;15(1):57-66.

50. Dols J, Landrum P, Wieck KL. Leading and managing an intergenerational workforce. Creat Nurs. 2010;16(2):68-74

51. Tang JHC. Evidence-based protocol: nurse retention. J Gerontol Nurs. 2003: 29(3):5-9.

52. Bethune G, Sherrod D, Youngblood L. 101 tips to retain a happy, healthy staff. Nurs Manag. 2005;36(4):24-9.

53. Gullatte MM, Jirasakhiran EQ. Retention and recruitment: reversing the order. Clin J Oncol Nurs. 2005;9(5):597.

54. Bowers BJ, Esmond S, Jacobson N. Turnover reinterpreted: CNAs talk about why they leave. J Gerontol Nurs. 2003;29(3):36-43.

55. Muse LA, Wadsworth LL. An examination of traditional versus nontraditional benefits. J Manag Psychol. 2012:27(2):112-31.

56. Chan YY. Job satisfaction, stress and mental wellbeing of health care workers in a regional public hospital. 香港大學學位論文. 2012:1-0.

57. Kumar R, Ahmed J, Shaikh BT, Hafeez R, Hafeez A. Job satisfaction among public health professionals working in public sector: a cross sectional study from Pakistan. Hum Resour Health. 2013;11(1):2.

58. Ryan RM, Deci EL. Self-determination theory: Basic psychological needs in motivation, development, and wellness. Guilford Publications; 2017.

59. Alshmemri M, Shahwan-Akl L, Maude P. Herzberg's two-factor theory. Life Sci J. 2017:14(5):12-6.

\section{Publisher's Note}

Springer Nature remains neutral with regard to jurisdictional claims in published maps and institutional affiliations.

\section{Ready to submit your research? Choose BMC and benefit from:}

- fast, convenient online submission

- thorough peer review by experienced researchers in your field

- rapid publication on acceptance

- support for research data, including large and complex data types

- gold Open Access which fosters wider collaboration and increased citations

- maximum visibility for your research: over $100 \mathrm{M}$ website views per year

At BMC, research is always in progress.

Learn more biomedcentral.com/submission 